\title{
A Regional Innovation System in Gestation: Guangdong
}

Rigas Arvanitis et Eglantine Jastrabsky

\section{OpenEdition}

1 Journals

Édition électronique

URL : http://journals.openedition.org/chinaperspectives/573

DOI : 10.4000/chinaperspectives.573

ISSN : 1996-4617

Éditeur

Centre d'étude français sur la Chine contemporaine

Édition imprimée

Date de publication : 1 février 2006

ISSN : 2070-3449

Référence électronique

Rigas Arvanitis et Eglantine Jastrabsky, " A Regional Innovation System in Gestation: Guangdong », China Perspectives [En ligne], 63 I january - february 2006, mis en ligne le 01 février 2009, consulté le 28 octobre 2019. URL : http://journals.openedition.org/chinaperspectives/573 ; DOI : 10.4000/ chinaperspectives.573

Ce document a été généré automatiquement le 28 octobre 2019.

(C) All rights reserved 


\title{
A Regional Innovation System in Gestation: Guangdong
}

\author{
Rigas Arvanitis et Eglantine Jastrabsky
}

1 Guangdong province, and the Pearl River Delta in particular, are the areas that have experienced the highest rate of industrialisation in China since the launch of the reform policy in 1978. Up to the end of the 1990s, a considerable number of private enterprises-but under a wide range of forms of ownership-were created through local initiative. The region thus experienced a two-fold process: the creation of small enterprises specialising in often traditional industrial production, and the formation of specialised production zones. From 1999, the provincial government sought to stimulate the improvement of production techniques and of basic technologies in the region. This public initiative coincided with a private dynamic and contributed to raising the level of industrial performance in the Delta. The question is whether the region will manage to make the technological transformation which is essential to the future competitiveness of its industry. The transformation of even a high-performance industrial area into a system of innovation, where governments, universities and enterprises interact in a permanent fashion in order to innovate and create a region on the cutting edge of progress, remains a difficult objective to achieve. It seems that the local authorities, rather than having an innovation policy-which is to say taking measures which would make it possible to structure interactions-, have sought to support enterprises or groups of enterprises on a one-off basis, through a succession of experiments.

2 While the region lacks universities of renown and research centres of national standing, investments by enterprises in Research and Development (R\&D) are higher there than in the other Chinese provinces. This characteristic, which is close to the situation experienced by Singapore in the early $1980 \mathrm{~s}^{1}$, has been the starting point of this research. After setting out the development of industrial and technology policy in Guangdong at the end of the 1990s, we will concentrate on a study of the role of enterprises in R\&D and on an analysis of the effects that the policies of specialised 
industrial zones, aimed at developing applied research and innovation, can have on the emergence of a system of innovation.

This article is based on a report drawn up by a team of researchers and professors under the authority of the Office of Science and Technology of Guangdong province, which we will henceforth refer to as the "Blue Report", after the colour of its cover2 This is the only report available that brings together all the data at provincial level. Our analysis of the report is guided by the specialised literature on the question, and by interviews with local authorities and enterprises carried out by the team from the Franco-Chinese Centre for the Sociology of Industry and Technology, in collaboration with the Institute for Research and Development of Guangdong University (Sun Yat-sen University in Guangzhou), between 2000 and 2004².

In May 1998, the Communist Party (CP) of Guangdong province took a decision to promote scientific and technological progress, to modernise industrial facilities and "to make enterprises the source of innovation". Shortly afterwards came the publication of Report No. 16 entitled "On the decision to rely on scientific and technological progress to attain a higher level of production in Guangdong"4. The same year, the Guangdong provincial authorities committed themselves to the development of science teaching and to setting up a system of innovation, "which is to say to favour the grouping of enterprises, to attract foreign investment and multinationals and to create a productive environment, particularly in the technology belt of the Pearl River Delta"5. This definition of the system of innovation is closer to that of an efficient production system-a group of enterprises which are in competition or linked by commercial ties from suppliers to customers-than to a system of innovation, which is a set of interactions between the educational, scientific, technological and economic systems ${ }^{6}$. In Guangdong there is a lack of both the scientific component and innovation proper, which is to say the introduction of new products and processes in enterprises.

51999 marked a turning point in China, with the approval of a national policy for stimulating the industrial and technological development of Chinese enterprises. Innovation became the buzzword. The novelty lay in the recognition given by the authorities to collective technology enterprises ${ }^{7}$ in the widest sense, designated as bearers of technological progress. For ideological reasons, the central authorities could not promote private enterprises in the early days of reform, whence the emergence of this category of enterprises, situated between the enterprises of the centralised economy and those of the free market. They were able to develop in Beijing by the 1980s, and above all during the 1990s, with the creation in 1991 of the high technology development zone of Zhongguancun. In 1999, concrete measures to promote high technology were decreed in order to solve the crucial problem of lack of internal resources, including subsidies, tax reductions for R\&D spending, tax exemptions on revenue derived from the transfer or development of new technology, a preferential Value Added Tax (VAT) rate of $6 \%$ for any software produced and developed in China, a total exemption from VAT, and subsidies for any exports of high technology. This evolution was particularly noticeable in Guangdong, since it was at that time that the local authorities realised that the development model fuelled by foreign direct investment (FDI) was not sufficient to improve the intrinsic capabilities of local enterprises. Beginning in 1998, Guangdong began to reform its system of scientific research, by integrating enterprises more closely and committing them to setting up 
R\&D centres. In early 2000, the province decreed measures of technological support for enterprises, with the policy of "industrial clusters".

Reform of the national research system began in the mid-1980s ${ }^{8}$. After initial restructuring, in particular of the relations between the technology centres of the large enterprises and their state supervisors, the major policy of the central government was to reduce the funds allocated to public research institutions. Research institutes and centres had to find non-governmental financing ${ }^{9}$. The positive consequences have been a better fit between research and the needs of the market, and a diversification of the areas of research. Moreover, some Chinese enterprises have developed in-house R\&D units. However, this way of integrating enterprises into the system "from below", has led, for research institutions, to an increase in small-scale, short-term projects, with smaller budgets, and generally to a levelling-off of progress in research, since overall, enterprises have not been involved in defining or initiating government research programmes. Moreover, the national policy which consists in eliminating or privatising a very high number of research centres of national standing is also called into question by some observers, who, like Cao Cong or Adam Segal, have noted rigid separations between the world of the university and that of enterprise ${ }^{10}$. The task is enormous since it is a matter of reforming the Academy of Sciences (reducing the number of centres and of personnel, who have been cut by more than 20,000), changing 1,618 public research institutes into enterprises (a reform which is well under way, since among the technological development centres which were dependent on provincial and municipal governments, some $70 \%$ have been registered as enterprises). Some 205 institutes which depended on various ministries (Agriculture, Territory and Resources, Water Resources, the Bureau of Forests and the Weather Bureau) have also been transformed ${ }^{11}$.

7 Economic analyses of Guangdong province usually concentrate on the creation of enterprises and on foreign investment. These were indeed the real engines of development which were superimposed-that is the right word-on the old socialist production structure ${ }^{12}$. Guangdong is at present the richest province in China, since it receives over one-third of FDI in China, and its exports of high technology account for $35 \%$ of China's total.

8 The relative paucity of state enterprises ${ }^{13}$, the lack of heavy processing industries (basic chemicals and steel) and the relative political autonomy enjoyed by the province in Deng Xiaoping's time, as well as the proximity of Hong Kong and Macau, gave the province a decisive advantage. However, as the Blue Report shows, these advantages for the development of light assembly industry became handicaps when it came to raising technological capacity ${ }^{14}$. Neither Hong Kong nor foreign enterprises really invested in high technology. The main problem is that FDI cannot substitute for the development of internal technological capacity, because foreign companies only transfer high value added activities if they are sure to find raw materials and equipment in large quantities.

9 "In Guangdong, total investment in R\&D was 1.942 billion yuan and 2.870 billion yuan in 1996 and 1997 , or $0.3 \%$ and $0.39 \%$ of the province's GDP"15. In 2000, investment exceeded 10 billion yuan (US $\$ 1.2$ billion) amounting to $1.11 \%$ of GDP-a little less than Beijing (over 15 billion yuan of R\&D spending) but more than Shanghai (7.4 billion yuan) [figures from October 2001]. However, in percentage of GDP, Guangdong is in 
third place, behind Shanghai, an indication of the relatively low level of its research investment.

1.Research and Development (R\&D) Spending in 2001

\begin{tabular}{|c|c|c|}
\hline & Yuan (billion) & GDP $(\%)$ \\
\hline Beijing & 15.5 & 6.30 \\
\hline Guangdong & 12.5 & 1.18 \\
\hline Shanghai & 8.8 & 1.78 \\
\hline Jiangsu & 8.2 & 0.90 \\
\hline Total China & 96.0 & 1.00 \\
\hline
\end{tabular}

Generally speaking-and this is surprising-the report states that the financing of research institutions is declining. Now, during the 1990s, the central government's spending on basic research, both applied and experimental, remained stable. In 2000, national R\&D spending was 89 billion yuan, an increase of $18 \%$ over the previous year, reaching $1 \%$ of GDP. Only $7 \%$ of total spending was then allocated to basic research (figures from the Ministry of Science and Technology, but only 5.2\% according to the Blue Report). Despite an improved sharing out of resources, the benefits of investments were uncertain ${ }^{16}$. The World Bank report ${ }^{17}$ explained this apparent contradiction between the increase-for over ten years-in the share of R\&D in relation to GDP, and the decline in resources of the research institutions, by the increase in costs and by the lack of transparency in allocations. In reality, it does seem that the recent period has seen a massive reorientation of public spending towards less centralised facilities, which are more dependent on local authorities and carry out much more finalised work. Their reorientation was accompanied by the dismantling of central research centres that were supposed to be carrying out finalised research. The finding of the authorities in 2002 was that "a number of questions have not yet been resolved, such as that of the modernisation of equipment" ${ }^{18}$. In China, the central government remains the principal source of financing for R\&D, but, as the Blue Report points out, "this funding is too low to allow research facilities to engage in sizeable long-term projects: facilities coexist without any selection and lack their own initiative" ${ }^{19}$. 


\begin{tabular}{|c|c|c|}
\hline & \multicolumn{2}{|c|}{$\begin{array}{l}\text { Number of personsumber of } \\
\text { engaged in scientists } \\
\text { S\&T activitiesand enginee } \\
\text { (per thousand inhaperathousand int }\end{array}$} \\
\hline Beijing & 240.4 & 174.2 \\
\hline Shanghai & 158.7 & 102.0 \\
\hline Guangdong & 54.5 & 31.5 \\
\hline Jiangsu & 70.6 & 36.1 \\
\hline Total China & $3,190,000$ & $2,004,000$ \\
\hline \multicolumn{3}{|c|}{$\begin{array}{l}\text { Source: Blue Report, op. cit., table } 4-17, \text { p. } 213 \text {. } \\
\text { NB: According to the Ministry of Science and Technol } \\
\text { in } 2000,3.223 \text { million people engaged S\&T activities } \\
\text { and engineers in S\&T activities, and } 698,000 \text { scienti } \\
\text { This last figure increased enormously between } 2000 \\
\text { scientists and engineers in R\&D. See note } 11 \text {. In } 200 \\
\text { of personnel engaged in S\&T activities had remained } \\
\text { and engineers and that of people in R\&D increased si } \\
\text { there were real reductions in the personnel of techn } \\
\text { centres, at all levels. }\end{array}$} \\
\hline
\end{tabular}

11 Guangdong enjoys the benefit of a fairly well-trained technical work force: of the province's total population, 238 out of every 10,000 have a qualification in a technical specialisation and 1,886 employees out of every 10,000 have a technical specialisation. In terms of this indicator, Guangdong is in second place at the national level ${ }^{20}$. But the province has a major weakness in terms of high-level cadre training and lacks scientists and engineers. The average level of education is below the national average, whether in terms of young people attending university or in terms of the quality of the teachers. What the Blue Report hints at, and which is also confirmed orally by various leaders, is that the high average technical level of the province is due to the immigration of young graduates from other Chinese provinces, attracted by the employment possibilities. Training is a paramount objective for the next few years. For example the universities have set up adult training systems on Saturdays and Sundays, mainly in management (in the form of MBAs or EMBAs). This market has become extremely competitive, particularly in Shenzhen. In this city are to be found training programmes from several universities, from Guangzhou and other cities (particularly Beijing). Companies pay for these training programmes, which are often very expensive, for their cadres for at least three reasons: they acquire a vocabulary and management models which correspond to international models, they can build networks of personal relations with cadres from other enterprises, and finally these courses are a token of prestige for enterprises which then advertise the high level of training of their cadres-an important criterion of the enterprise's reputation in the eyes of the authorities, competitors, customers and suppliers.

In China enterprises invest little in R\&D: the share of their investment has even declined. Large and medium enterprises invested 1.39\% of their income in R\&D in 1991, $1.15 \%$ in $1995,1.35 \%$ in 1999 , and $1.6 \%$ in 2001 . Guangdong, according to the Blue 
Report, shows better results in terms of enterprise investment than the other Chinese provinces $^{21}$. Enterprise investment amounted to $88 \%$ of overall investment in 2000 (9.520 million yuan) and 90\% in 2001 (11.370 million yuan).

3. Resources and Spending in Science and Technology of the Principal Municipalities of Guangdong

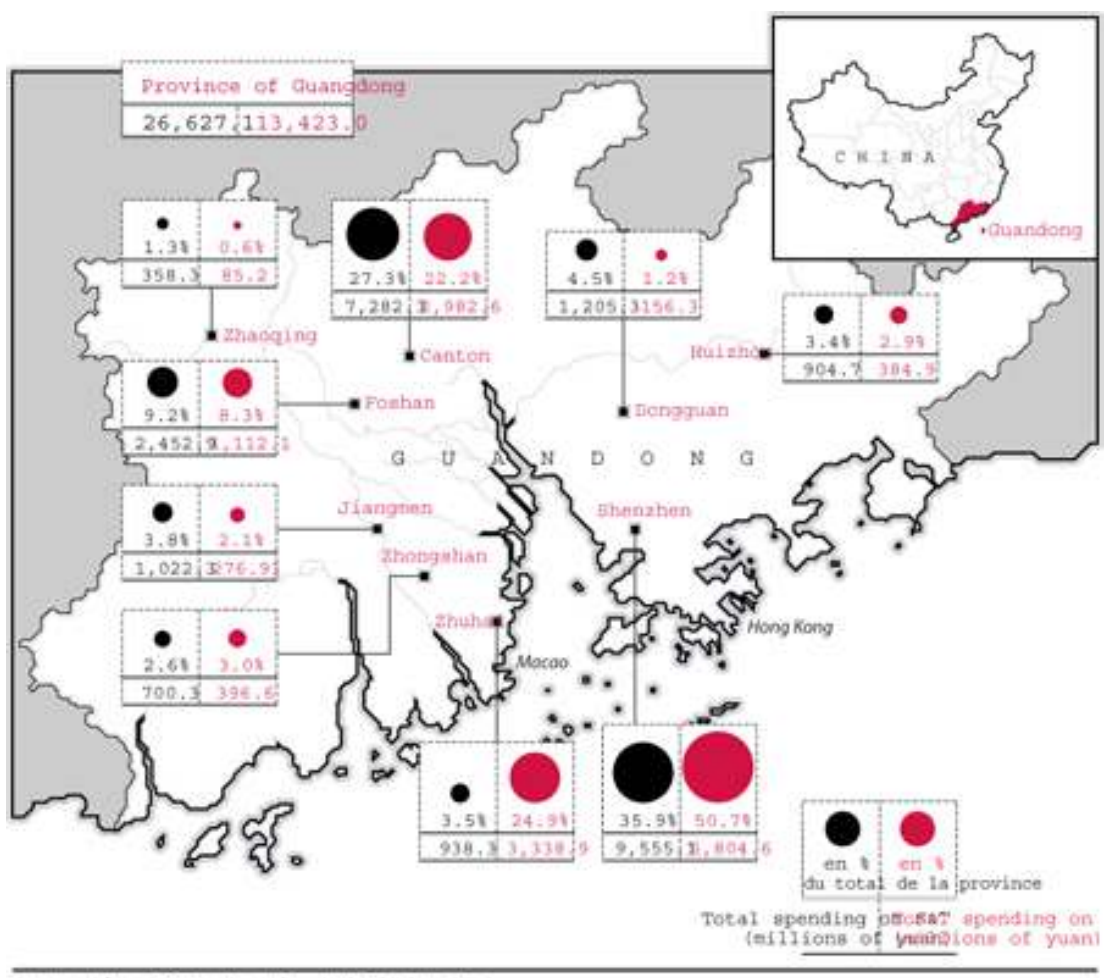

Scarce: Hive keport, op. eit,., table 7, p. 25\%

13 At the beginning of 2001, there were 2,733 "technological and scientific research facilities", employing 95,400 scientists and technicians, about double the figure in 1995. It is the city of Shenzhen which has carried this development the most: in 2001, it had 521 R\&D facilities, of which $91.7 \%$ were set up by enterprises. In 2001, 26 development centres of the most productive enterprises had developed 459 new products, and 440 patent registrations, of which 161 were for inventions. Their investment in research had reached the sum of 4.220 billion yuan, or $6.62 \%$ of their total revenue (over $10 \%$ for Huawei and Zhongxing (ZTE), leading electronics enterprises) ${ }^{22}$. In 2001, 65,000 patents were issued in China, and Guangdong accounted for over half of these registrations. Obviously this reflects the technological dynamism of the province, but also the scale of foreign investment in the province, for most invention patents in China are taken out by foreign enterprises, while Chinese enterprises tend to register utility models and design ${ }^{23}$.

\section{Patents Registered in Guangdong}

\begin{tabular}{|c|c|c|c|c|c|}
\hline & 1997 & 1998 & 1999 & 2000 & $\begin{array}{l}2001 \\
\text { iestinared }\end{array}$ \\
\hline Number of patenta regietered & 12,858 & 13,473 & 16,802 & 21.123 & 27.596 \\
\hline Wumber of patenta granted & 7,171 & 10,707 & 14,328 & 15,799 & 18,259 \\
\hline
\end{tabular}

Sourcer thue heport, op. e1t., Table annex f., pp. 246-249. 
In the Special Economic Zone of Shenzhen, and to a lesser extent in Zhuhai, the authorities carried out an offensive to develop the technological capacity of enterprises during the 1990s, but such was not the case in Guangzhou. In Shenzhen, the growth of R\&D facilities in enterprises was carried out on the basis of investment in electronics (both national enterprises and those with foreign investment) above all, and by basing itself on the collective technology enterprises' capacity for development. However, according to Adam Segal, Shenzhen constituted a case apart in the region. The authorities in Guangzhou, in his view, and those in Guangdong province, according to our own observations, were slow to promulgate policies to support high technology enterprises. Guangzhou thus faced strong competition from Shenzhen, which managed to tap into the flow of qualified personnel.

\section{Research Organisations in Guangdong}

\begin{tabular}{|c|c|c|c|c|}
\hline & 1992 & 1998 & 1999 & 2000 \\
\hline Independent research organinations & 477 & 476 & 474 & 445 \\
\hline Research organisations on university campuse & es 195 & 393 & 375 & 343 \\
\hline $\begin{array}{l}\text { Technieal development organisations } \\
\text { in large and medium enterprises }\end{array}$ & 587 & 728 & 791 & 3.732 \\
\hline $\begin{array}{l}\text { Number of large and medium enterprisen } \\
\text { with at least one techinical development ory }\end{array}$ & $\begin{array}{l}527 \\
\text { inimation }\end{array}$ & 502 & 535 & 529 \\
\hline Droportian of the total of large and nedful & ertapysin & 23,81 & 26,21 & 25.71 \\
\hline
\end{tabular}

In Guangdong, most R\&D centres are set up within enterprises, which provide $70 \%$ of the funding and are responsible for $65 \%$ of so-called high technology products. In 1998, $23.8 \%$ of major enterprises (including national enterprises, the big groups and enterprises with foreign capital) had their own R\&D centres, in $199926.2 \%$, and in 2000 $25.7 \%$. In $2001,85 \%$ of small and medium collective technology enterprises operating in the technical sector had an R\&D centre: of the 25.600 billion yuan invested in science and technology in Guangdong, $71.4 \%$ came from the province's enterprises. Large and medium enterprises invested 9.450 billion yuan that year, or 4.172 billion yuan more than in 1997. This movement of creation of R\&D centres was not due to a political initiative from the authorities, but rather to the transfer by certain foreign companies of part of their R\&D activity to China, and to particular support for certain enterprises by their Chinese supervisory authorities. When the Guangdong authorities recognise the importance of enterprises in the development of a system of innovation, they do not play a decisive stimulation role, but ratify a largely spontaneous evolution. Thus, when the deputy mayor of the city of Jiangmen confides during an interview that science and technology are an essential aspect of economic development, this does not translate into specific measures for enterprises, but into greater tolerance for motorcycle and washing machine manufacturers, who are more advanced technologically compared to the other industries in the municipality.

The term "collective technology enterprise" designates enterprises whose ownership is public, even though most of them function de facto like private enterprises. The Blue Report defines them by their orientation to the market and their responsibility for profits and losses ${ }^{24}$. These enterprises have been the institutional form of the most dynamic enterprises all over the country. The major Chinese brands which are well known abroad, such as TCL, Hai'er and Legend (now LeNovo), are collective technology enterprises which have been privatised to varying degrees. The major brands in 
Guangdong, such as Meidi (Midéa), Galanz, GREE and Kelon, are in a similar situation. Enterprises such as Jinlin (domestic appliances) and Jinyue (electronic components), are "privatised" public enterprises, which maintain close contact with their supervising official bureau. The next few years should see a gradual modification of the legal status of these enterprises.

At the end of the 1990s, the recession in Asia, and in the public enterprises, the progress of the negotiations for China's accession to the World Trade Organisation (WTO), combined with doubts about the effects of previous policies, led to major changes in relations between the state and collective enterprises. The Chinese authorities became increasingly preoccupied with not missing the next wave of technological innovation, particularly in Guangdong, where enterprises were better known for their copies of major brands than for the creation of new products. In Guangzhou, the authorities allowed these kinds of enterprises to register in the category of private enterprises (siying qiye, WWWW), without defining them as separate entities, with specific organisation and technological and financial needs.

In 2001, there were 3,952 collective enterprises ( $0.99 \%$ of enterprises in Guangdong), with a turnover of over 103 billion yuan, over 8 billion yuan in profits, employing 314,000 people, paying over 7 billion yuan in taxes, and providing exports worth over US $\$ 2$ billion. These enterprises accounted for only $7.25 \%$ of production value and only $2 \%$ of total exports. In the two cities where they were most numerous, Shenzhen and Guangzhou, they produced respectively only $10 \%$ and $11 \%$ of the value of industrial production. They were generally small, employed an average of seventy people and had a production value which did not exceed one million yuan per year. The enterprises which most developed technological innovation products were those said to have "three sources of capital" (public, private and international) which we usually call "joint companies"25.

6. Collective Science and Technology Entreprises in Guangdong

Number of collective science
and technology enterprises

Despite their low proportion among the total number of enterprises in Guangdong, the collective enterprises accounted for a little less than $30 \%$ of the value of cutting-edge industrial production, and $88 \%$ of their products were "high technology". Table 6 shows an estimate made by the province's services of the number of high technology collective enterprises. The number of these collective enterprises increased significantly during 2001. In Guangdong's ten zones for the special development of cutting-edge technology at national and provincial level, these enterprises represented about $80 \%$ of those in operation. In Shenzhen, in 2001, they accounted for 22 billion yuan of high technology production.

These were also the enterprises which invested the most in R\&D. In 1997 their R\&D investments did not exceed 1.5 billion yuan. Between 1997 and 2001, these investments grew by an average of $60 \%$ a year, reaching 5.892 billion yuan in 2000 and 7.150 billion in 2001, over half the investments made in the province that year. In the last few years, 
(before 2001) these enterprises developed over 3,000 new products, of which $70 \%$ are protected by intellectual property law. In 2001, they deposited 3,514 patents, of which 2,763 were registered.

21 Guangdong has been the leading province in electronic products since the early 1990 s. In 2000, production of electronic equipment and software reached 300 billion yuan. Guangdong had 21 of the 100 leading Chinese enterprises in this sector, among which were three of the ten leading national companies. The Pearl River Delta specialised in the manufacture of these appliances ${ }^{26}$. The authority's aim was to develop this sector further in order to allow the region to compete with Beijing and Shanghai ${ }^{27}$.

Take-off took place in 1991, with production worth over 18 billion yuan, an increase of $73 \%$ over the previous year. During the eighth Five Year Plan, annual growth in the sector was about 38\% (1991-1995). In 1995, the electronics factories in Shenzhen and Huizhou accounted for $67 \%$ of the province's total production value (sales at Huaqiang, Kangjia, Saige and TCL exceeded 3 billion yuan in 1995) ${ }^{28}$.

23 The province's "three industrial pillars", electronics/computers, electrical equipment and petroleum derivatives, went from 253.334 billion yuan in 1997 to 311 billion in 2001. In 1998, these three industrial sectors amounted to $37.6 \%$ of the province's total industrial production, and to $45.4 \%$ in 2001 . The share of electronics and computers rose from $16.4 \%$ to $22.2 \%$ during that time.

In 1997, sales of Guangdong software brought in only 2.5 billion yuan; in 2001 it was 10 billion yuan for software and 26 billion yuan for systems, around one-third of overall sales for the whole country. In 2001, over 2,000 enterprises were engaged in development and sales of software, mainly in Guangzhou, Shenzhen and Zhuhai, and to a lesser extent in Nanhai, Dongguan and Shunde. However the authors of the report point out that China is lagging behind India in research and in the training of computer experts. This is why the development of this sector has been one of the objectives of the tenth Five Year Plan (2001-2006).

In this sector, as in all of its production, Guangdong is characterised by a stronger orientation towards exports than the rest of the country. Exports of so-called "high technology" products in this region increased by $30 \%$ between 1999 and 2001. The socalled high technology sector as a whole accounted for over $23 \%$ of the province's exports in 2001. 2002 showed a continuation and even an increase in the same trend ${ }^{29}$.

Although the definition of the high technology sector includes many enterprises which are limited to assembling imported components ${ }^{30}$, or even produce obsolete equipment (often by choice, as we saw in our interviews, for there is national demand for inexpensive equipment), the fact remains that the province turns shows a quite good performance in comparison with other countries which export electronics. It must however be emphasised that this push in the electronics industry was first initiated by foreign investment, mainly from enterprises in Taiwan and Hong Kong. As we shall see, the local authorities initially sought to attract an increasing number of foreign enterprises to the technology development zones, and subsequently sought to build up the technology capacity of Chinese SMEs by creating "industrial clusters". The limitations of these policies are the lack of real future prospects, and support for the reproduction, rather than the production, of new techniques.

March 1986 saw the launch of the national programme called "863", which sought to develop cutting-edge scientific research, shortly after the creation, in June 1985, of the 
Shenzhen industrial park ${ }^{31}$. In 1988, the central authorities published the "Torch" programme, which sought to harness the growth of collective enterprises to the development of scientific parks. Following this national programme, in 1991 the authorities in Guangdong set up 27 high technology development zones, of which Zhongshan, Tianhe in Guangzhou, and Shenzhen were the models ${ }^{32}$. In 1992 and 1993, it was the turn of Foshan, Huizhou and Zuhai to become high technology development zones. In 1991, the central authorities accepted the proposal of the Guangdong government to create the Delta's high-tech development belt, which aimed at competing with that of Jiangsu (Suzhou, Wuxi, Changzhou) and that of Shanghai.

\section{The Industrial Cluster Policy}

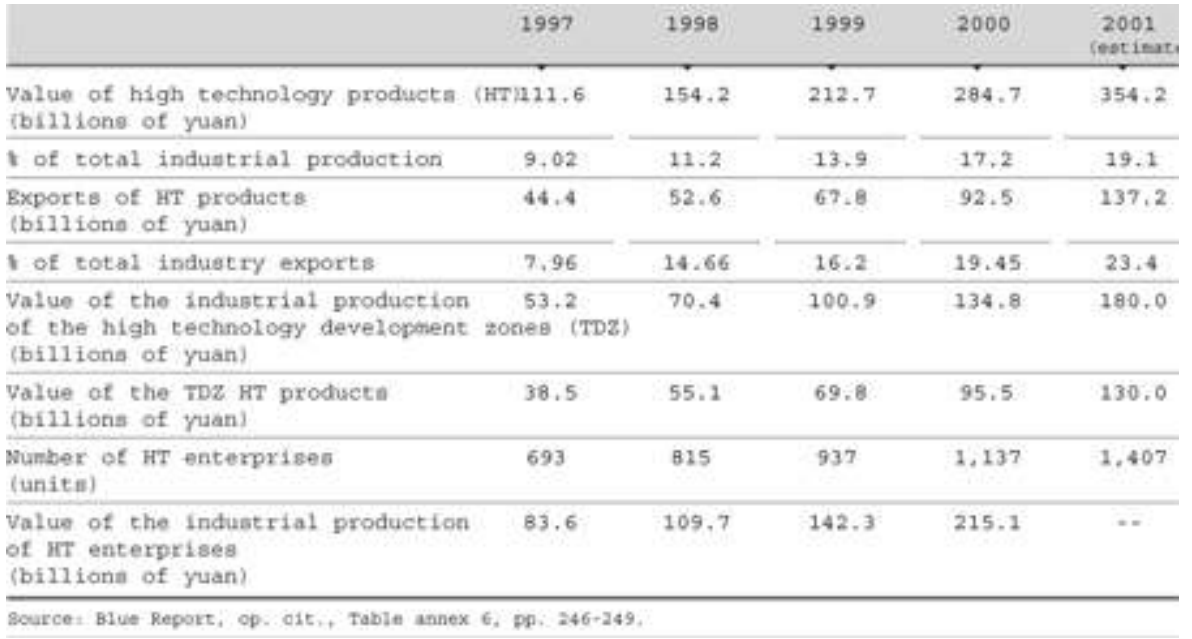

This voluntarist policy produced results: the boom in production took place around 2000 , with the total production of these special zones rising from 50 billion yuan in 1997 to 180 billion in 2001. Moreover, total production of high technology products rose from 111 billion yuan in 1997 to 354 billion yuan in 2001, with 132 billion in Shenzhen (46\%), 61 billion in Guangzhou, 47 billion in Foshan, a little over 20 billion each for Dongguan and Huizhou, and between 12 and 17 billion for Zhuhai, Jiangmen and Zhongshan. Shenzhen and Guangzhou were designated as spearheads in the development of cutting-edge technology by Guangdong province in 1998. In these two cities were developed the first cutting-edge industrial zones in the electronics and computer sectors. In Shenzhen the total value of production in the special high technology production zones exceeded 63 billion yuan in 2001, 17 times the value in 1996. Over half of the production was protected by intellectual property law. $98 \%$ of production there was in electronics and computers.

The city of Zuhai's innovation policy was to attract multinationals. In 2001, the total value of the production of these special zones reached 10 billion yuan. In Zhongshan, the special technology zones produced 26 billion yuan, or a quarter of the city's industrial production and 7 billion more than the previous year.

Between these major zones have developed small and medium industrial cities, which tended to become localised industrial systems ${ }^{33}$-which we shall call, in the rest of this article, clusters, the English word used in Chinese-in more traditional sectors, such as construction, plumbing, furniture and leather. The policy of developing the technology zones was very different in nature from that of the industrial clusters. 
31 The term specialised cluster (zhuanye zhen) is an administrative name which the authorities give a locality in order to avail of specific support in the framework of subsidies for technological development. This designation facilitates the establishment of centres for innovation and technology development in sectors such as steel, furniture, textiles, construction, etc. It is no longer a question of merely defining a specific zone to function as a magnet for foreign investment, but of improving the technical and technological capacities of local enterprises by the creation of this kind of structure. In contrast with the local production systems in France or the industrial districts in Italy, the specialised product clusters are an official designation which make it possible for municipalities to obtain subsidies from the province. In 2000, the Department of Science and Technology of Guangdong officially launched a pilot project aimed at encouraging the development of scientific and technical innovation at district level and therefore to support growth of their economy. At that time, 78 districts were chosen; some were even designated as models of technological innovation. In July 2002, the province drew up a list of 38 localised innovation and technology centres in specialised localities (see Table 8 for a partial list of specialised localities) ${ }^{34}$. Among the objectives of the innovation centres, research activities, in liaison with the universities and public institutions, are among the most important. However this denomination covers small technical bureaus as well as real technology centres. Thus for example the locality of Suikou, in the municipality of Kaiping (Jiangmen), which specialises in taps (or "faucets" as is the American word) and plumbing, had no innovation centre, but the local government invested 1 million yuan in the creation of an Internet B2B (business to business) service for the tap industry. This unit, which became an independent enterprise in 2002, is probably exactly the kind of interface which the locality needed ${ }^{35}$. In fact, of the 415 industrial groupings to be found in the Delta, a quarter can be considered as "industrial clusters" ${ }^{36}$. They are destined to become the favoured sites for innovation. A research programme carried out by the Institute for the Development of Guangdong at the University of Zhongshan (Sun Yat-sen) made it its main field of research ${ }^{37}$.

In Nanhai, nine technical innovation centres were set up within traditional industries such as ceramics, textiles, clothing, aluminium products and foodstuffs. Furthermore, a large number of enterprises sought to create in-house R\&D units. In Pingzhou, we visited a shoe manufacturing SME which employed 150 people; in a corner of the production workshop, a young man and a young woman were designing shoes in a big drawing book, detailing entirely by hand the shapes of the shoes to be cut out: this was the R\&D unit.

In reality, most enterprises are short of funds, techniques and qualified personnel. According to the Blue Report, the owners are peasants who have prospered but have no industrial experience. Our observations are more complex, since in many specialised localities, the bosses are former workers in production brigade and people's commune enterprises which have become locality or district enterprises. While their technical knowledge is rudimentary, they nevertheless have real competencies in their sector (for example in founding, mechanics, electrolysis or galvanising).

The development of the municipality of Nanhai shows some particularities. The grouping together of its enterprises took place long before the policy of formation and subsidy for clusters. In Nanhai it was decided to "give the manufacturing sector its own path". Thus each zhen (W, locality, an administrative unit smaller than a municipality) 
became a unit of reference. The innovation centres structured them individually, in order to ensure the promotion of computer and production techniques, and to spread commercial information. The metal and mechanical industry in Jinsha brought together in Nanhai some 4,000 enterprises which amounted to a production worth 10 billion yuan, $10 \%$ of national industry and $40 \%$ of industry at provincial level ${ }^{38}$. Half the production was exported to Europe, Southeast Asia and the Middle East. Today, Jinsha has 1,000 enterprises whose production exceeds 1 billion yuan, of which $98 \%$ are family SMEs. They have no innovation capacity and the quality of their production is low. An innovation centre was set up in September 1999. At the same time collaboration was set up with the local Huazhong university to create an R\&D enterprise and other research structures. A development centre for new products was established including a unit specialising in the design of steel moulds for extruding machines. This technology made it possible to reduce the design time for new moulds from 30 to 7 days. Since its establishment, this innovation centre has created over 100 new products.

8. List of Industrial Clusters in Guangdong Province

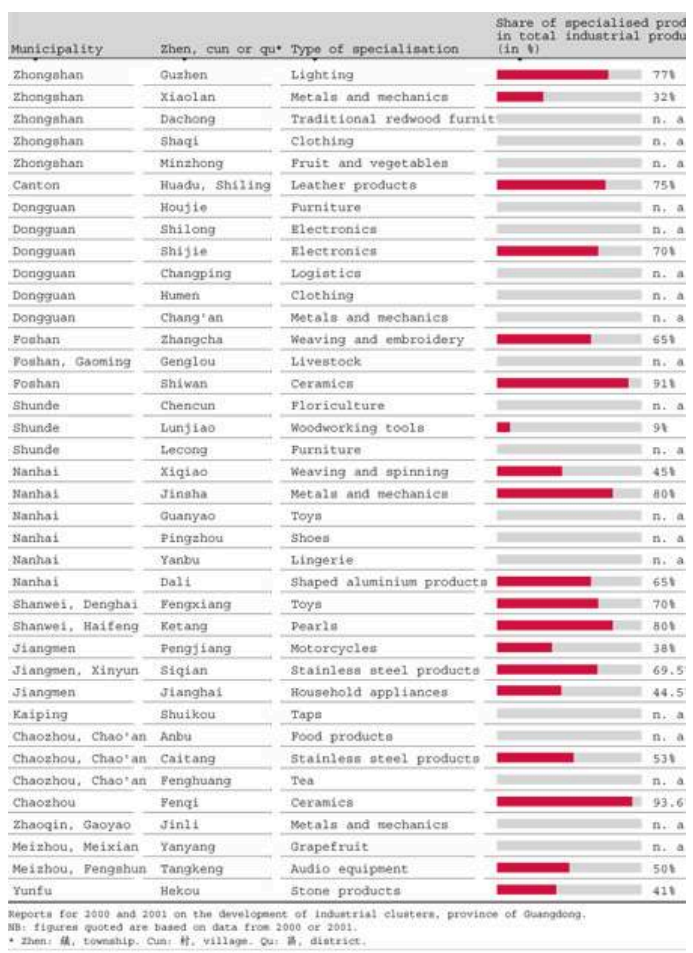

Xiqiao and its cotton textiles industry is the perfect example of the success of this policy. The locality had 1,670 textile enterprises for the printing and spinning of all kinds of fabrics, for both furniture and clothing. The annual sales of this locality amounted to 13 billion yuan. The sizes of the factories were so small and so varied, and the technical level so low, that the enterprises could see no point in initiating R\&D activities. In May 1999, the government set up an innovation centre. Since then the centre has created over 8,000 products (computer assisted textile designs). Every day the centre's personnel visit the enterprises. This is how Xiqiao is moving from imitation to innovation. The centre also has clients in the provinces of Zhejiang and Hunan, as well as in Taiwan. The initial investment was 7 million yuan, and the centre quickly became self-sufficient by the sale of its services. Moreover, it participated in a major effort to computerise the enterprises, ensuring the development and 
maintenance of the local computer network. More recently, in 2004, the government of the province decided to set up a technical university specialising in textiles and to ensure that the locality of Xiqiao became a centre for technology development at a national level.

The policy of industrial clusters and the network of innovation centres which are attached to them make up the backbone of innovation policy in China, complementing the other major facets which are the technology development zones, the support given to certain enterprises, and the transformation of enterprises into public research centres ${ }^{39}$. The innovation centres have very strong links with local enterprises, particularly since they are a means for the computerisation of the enterprises, and because of their knowledge of local production conditions. It is this adaptation to local conditions which explains the differences between them. Each innovation centre adjusts to particular industrial structures and the nature of the production sector obviously greatly influences their functioning. The dynamic industrial clusters encourage these centres to become providers of product models. In the less dynamic clusters, their role is much more difficult to define. Information is often a central preoccupation but no previous experience of technology watch makes it possible for the centre employees to sell information, which in most cases is limited to Internet pages, and at best, to B2B systems. In reality the training and management needs of enterprises far exceed what these centres can provide. The weakness of links with the universities and technical schools makes this connection work even rarer and more difficult. Eventually, one of the functions of these centres will be to play an intermediary role between research organisations and enterprises, if they can manage to provide their own financing ${ }^{40}$.

The authorities in the province of Guangdong have understood the importance of supporting enterprises in their technological aspects. They have recently created a system of indicators in order to follow technological developments more closely. It has also been decided no longer to leave the initiative to local authorities alone, as they lack resources. Thus, in textiles, the decision to transform a local technical centre into a real technological and industrial development centre cannot depend on the local authority of the locality of Xiqiao. Finally, the provincial government has begun thinking about the optimisation of the technical centres, which, besides their technical functions, must contribute to the spreading of information and to networking with the universities.

Moreover, many industrial zones are seeing the establishment of owner's associations either on a sectoral or on a geographical basis. Local authorities seek to promote them in order to have an interlocutor. For the moment it is not possible to tell whether these associations will have any impact on the modernisation of enterprises.

41 We have concentrated on the industrial aspect alone, which represents the essential feature of the economic development of the province, and of the Pearl River Delta. This region has experienced what Gilles Guiheux calls the creation of a local economic space $^{41}$, following other researchers, geographers ${ }^{42}$, and economists ${ }^{43}$, who have shown the importance of the local rooting of industry in China, or more generally, in several developing countries ${ }^{44}$.

But in order to succeed in transforming an industrial space into a regional innovation space it is necessary to transcend local limits, particularly by creating stable links between suppliers and clients, by facilitating access to technology resources, setting up 
a qualified labour market and forging links with the universities. Guangdong has simultaneously to face threefold competition as well as structural difficulties.

The competition comes partly from foreign companies, which take little account of the technical centres and the growth of SMEs, and invest more and more in R\&D in China ${ }^{45}$. Foreign investors, from Taiwan, Hong Kong, Korea, Japan and the West, who are numerous in Guangdong, make up a separate group of economic players who are very little integrated into the local economy, and use the local space as if it were a mine, rich in cheap labour, even when highly trained (a CAD technician hardly costs more than a worker), and in infrastructure (the various incentives offered by local government to foreign investors). The competition also comes from other Chinese industrial regions seeking to access the resources of the central government. This competition is obvious at both local and provincial level. Lastly must be emphasised the particular competition of Beijing and Shanghai, cities which, because of their political status, monopolise high level scientific resources and receive preferential support to establish technology development centres. Their position reflects political choices which are not necessarily based on economic rationality, as is shown by the multitude of urban development plans which have benefited Shanghai, the pressures on multinationals to set up there, or the measures in favour of establishing companies in Beijing. Oddly, provincial political leaders never mention a threat from Asia. Only India is mentioned in the field of software development parks as an example to be followed and overtaken. Malaysia (a strong centre of techno-industrial development), Thailand and Singapore do not even rate a mention, either as competitors or as markets. And so it is that the enterprises themselves seem to aim more easily at Europe, the United States and America, central Asia and Africa, than at South or Southeast Asia.

The structural problems are related both to the legacy of the former socialist economy and to recent growth. The national private sector, which is particularly active in Guangdong, is beginning to claim a representative position, an attitude which is sometimes corporatist but very real, and which the state has to face for the first time in its history. The considerable power of local governments is being called into question, and negotiations to establish priorities in financing will not be easy. The lack of clear distinction between public and private, which was an advantage for the creation of SMEs, becomes a difficulty when it comes to supporting the technological upgrading of enterprises. Lastly the lack of confidence of enterprises vis-à-vis the collective (not to say the public) where links of trust, which are essential for the creation of enterprises, do not offer a configuration, constitute a further obstacle. For the moment enterprises are above all consumers of infrastructure and there are only rare cases where professional or industrial associations connect with local authorities.

Nobody can say today if enterprises and local authorities will succeed in setting up an innovation system, but two aspects point in that direction. The provincial government's thinking is particularly active and includes considerable observation on the ground. Far from being a diktat, it is a carefully thought-out policy drawing on both foreign experiments ${ }^{46}$ and on local reality. The government report we have used in these pages is evidence of this. This initiates a process of discussion, for example on the very nature of innovation activities, the role of the universities, the functioning of innovation centres, and the role of national and foreign enterprises. Moreover, enterprises inserted in industrial clusters inevitably maintain a symbiotic relationship with innovation centres, which counterbalance their shortcomings in technology and 
their strong links with foreign customers. The bringing together of political will, local resources, a dense industrial network and the fast learning of technology indicates a favourable outcome.

\section{NOTES}

1. On this subject one can reread the article by Yves Goudineau, "Etre excellent sans être pur : potentiel technologique et pouvoir technocratique à Singapour" (Being excellent without being pure: technological potential and technocratic power in Singapore), Cahier des sciences humaines, 26 (3), 1990, pp. 379-405.

2. Guangdong Office of Science and Technology, "Guangdong keji fazhan yanjiu baogao" (Report on the development of scientific and technological research in Guangdong), Guangzhou, Guangdong gaodeng jiaoyu chubanshe, December 2002, 256 p. Hereafter referred to as the Blue Report.

3. Research carried out in 2003 and 2004 under the direction of Professor Qiu Haixiong, in the industrial districts (or "clusters") of electronics in Qingxi (Dongguan), ceramics in Nanzhuang (Nanhai), aluminium in Dali (Nanhai), metal parts in Jinsha, textiles in Xiqiao, toys in Guanyao, industrial electronics in Songgong, shoes in Pingzhou, underclothes in Yanbu, vegetable production in Heshun, and motorcycles in Jiangmen. Research was also carried out in Shuikou (Jiangmen) in taps (faucets) and plumbing and in enterprises in various sectors around Guangzhou (glue, ceramics, washing machines).

4. Blue Report, op. cit., p.2.

5. Ibid., p. 120.

6. There is no accepted definition of an innovation system, but all the writers agree that it is a range of institutions devoted to research, teaching, technology development, the spreading of techniques and production. See Bruno Amable, Rémi Barré and Robert Boyer, Les Systèmes d'innovation à l'ère de la globalisation (Innovation Systems in The Era of Globalisation), Paris, Economica, 1997. We contrast this with the idea of an "efficient production system" which brings together a range of productive systems and thus of industrial enterprises which are in competition but connected by links between clients and suppliers. It is efficient when it "makes it possible to produce goods and services in the form and at the price required by demand": cf. Jean Ruffier, L'Efficience productive. Comment marchent les usines (Productive Efficiency. How Factories Work), Paris, Presses du CNRS, 1996.

7. Translation of the Chinese minying keji qiye (WWWWWW), which we prefer to the translation "non-governmental high technology enterprise" used by Adam Segal (Digital Dragon. High-Technology Enterprises in China, Ithaca and London, Cornell University Press, 2003), as it preserves the idea contained in the Chinese terms of an area of possible intervention by the local authorities.

8. The first reform of the technology research institutes took place during the 1980s and was described by Shulin Gu in China's Industrial Technology: Market Reform and 
Organisational Change, UNU/INTECH Studies in New Technology and Development, London, Routledge in association with UNU Press, 1999. A revision of the policy as a whole can be found in Carl Dahlman and J. E. Aubert, China and the Knowledge Economy. Seizing the 21st Century, Washington D.C., World Bank, 2002.

9. On this reform and in particular on its effects in Guangdong, see the article by Joshua Ka-Ho Mok, "Globalization and Educational Restructuring: Challenges and Responses of Higher Education in Guangdong”, in Joseph Y. S. Cheng (ed.), Guangdong: Preparing for the WTO Challenge, Hong Kong, The Chinese University Press, 2003, pp. 251-281.

10. We would be much more cautious about the supposed impermeability between the worlds of the university and of enterprise. Our interviews drew attention rather to institutional difficulties, in the sense that enterprises find it difficult to sign a contract with universities. But we have been able to observe a considerable number of personal agreements between academics in the fields of the applied sciences, and enterprises. This permeability sometimes goes beyond reason, for some professors neglect their university work completely to devote themselves to business.

11. These figures cannot be verified. They come from a range of official reports, and administrative divisions make the statistics completely opaque. However the movement to privatise public institutions has indeed taken place. See for example Yuli Tang, "Review of the reform of research institutes", Conference on China's New Knowledge Systems and their Global Interaction, September 29th-30th, Lund, Sweden, Swedish Agency for Innovation Studies, Stockholm School of Economics and Lund University, 2003, pp. 27-37.

12. We have elsewhere reinterpreted the well-known "Chinese miracle", cf. Rigas Arvanitis, Pierre Miège and Wei Zhao, "A Fresh Look at the Development of a Market Economy in China", China Perspectives, No. 48, July-August 2003, pp. 51-62

13. In 2001 , state enterprises represented about $20 \%$ of industrial production in Guangdong as against $45 \%$ in China as a whole.

14. Blue Report, op. cit., p. 123.

15. Blue Report, op. cit., p. 78.

16. Blue Report, op. cit., pp. 28-29.

17. Dahlman and Aubert, op. cit.

18. Blue Report, op. cit., pp. 26-27.

19. Blue Report, op. cit., p. 25.

20. Blue Report, op. cit., p. 120. The public statistics of the Ministry of Science and Technology (MOST) do not make it possible to differentiate at province level the data concerning the three major divisions of personnel (MOST follows the indications of the American NSF where its statistics are concerned): personnel engaged in S\&T activities; scientists and engineers engaged in S\&T activities; personnel engaged in R\&D.

Furthermore, these headings are not always adhered to when they are reproduced in other documents such as the Blue Report. Blue Report, op. cit., p. 78.

21. Blue Report, op. cit., p.78.

22. Blue Report, op. cit., p.67.

23. See National Bureau of Statistics and Ministry of Science and Technology, China Statistical Yearbook on Science and Technology 2003, Beijing, China Statistical Press, 2003, p. 434. See especially the article by Cong Cao, "Challenges for Technological Development in China's Industry", China Perspectives, No. 54, July-August 2004, pp. 4-16.

24. These enterprises define themselves by the "two refusals" (liang bu, WW) and the "four principles" (si zi, WW): the refusal to participate in a Five Year Plan and the 
refusal of government interference in their human resources management; the four principles are responsibility for their own development, organisation and functioning, as well as for their own profits and losses. (Blue Report, op. cit., p. 129).

25. Blue Report, op. cit., p. 125. There were said to be a total of 370,800 enterprises in Guangdong in 2000-not including very small enterprises with fewer then nine employees or 3,952 collective enterprises. On the analysis of so-called high technology collective enterprises, the authors of the Blue Report refer to research carried out in Shenzhen, Dongguan and Zhuhai, which has not been published.

26. Blue Report, op. cit., pp. 41-42.

27. A (rare) measured assessment of the electronics industry in China can be found in the article by Cong Cao, op. cit.

28. Blue Report, op. cit., p.134.

29. Blue Report, op. cit., p.119.

30. See Françoise Lemoine and Deniz Ünal-Kesenci, "China in the International Segmentation of Production Processes", CEPII Working Papers No. 2002-02, Paris, 2002; Francoise Lemoine and Deniz Unal-Kesenci, "Assembly Trade and Technology Transfer: The Case of China”, World Development, 32 (5), 2004, pp. 829-850.

31. A recent overview of science and technology policy is by Can Huang, Celeste Amorim, Mark Spinoglio, Borges Gouveia and Augusto Medina, "Organization, programme and structure: an analysis of the Chinese innovation policy framework", R \& D Management, 34 (4), 2004, pp. 367-387.

32. For an evaluation of this policy see Rigas Arvanitis, "La politique d'innovation en Chine - un essai d'interprétation" (Innovation policy in China-an attempt at interpretation), La Lettre de l'Antenne (Antenne expérimentale franco-chinoise de sciences humaines et sociales à Pékin, http://www.antenne-pekin.com), May 3rd 2004). 33. According to the definition given by the DATAR in France, a local production system is "a group of enterprises and institutions in geographical proximity who collaborate in the same sector of activity". DATAR, Les Systèmes productifs locaux, Paris, La Documentation française, 2002.

34. To our knowledge only 12 of these centres have been active and were linked in a network of "innovation centres". A web site was also set for this network: http:// www.zhyz.gov.cn/

35. Interviews in Shuikou, 2002.

36. Blue Report, op. cit., p. 119.

37. Under the direction of Professor Oiu Haixiong. We would like to thank the centre and Professor Oiu for their support during the analysis and research in the innovation centres. The following data in the article come from interviews.

38. Interviews in January 2004.

39. Arvanitis, 2004, op. cit.

40. Haixiong Qiu and Jianniu $\mathrm{Xu}$, “The Local Governments' Policy Concerning the Innovation Centers in Industrial Clusters" (in Chinese), conference paper (Regional Innovation Systems and Science and Technology Policies in Emerging Economies: Experiences from China and the World), Sun Yat-sen University, Guangzhou, April 19th-21st 2004, (forthcoming).

41. Gilles Guiheux, "Les ressources localisées d'une entreprise privée en Chine centrale" (The local resources of a privatised enterprise in Central China), Genèses, No. 56, Autumn 2004, pp. 51-71. 
42. Thierry Sanjuan, A l'ombre de Hong Kong. Le delta de la rivière des Perles (In The Shadow of Hong Kong. The Pearl River Delta), Paris, L'Harmattan, 1999.

43. Abdelkader Sid Ahmed, “ Technologies de l'information et développement économique local : enjeux et stratégies pour les régions et pays en développement du bassin méditerranéen" (Information technology and local economic development: stakes and strategies for developing regions and countries in the Mediterranean basin), in Antonio Sassu et Abdelkader Sid Ahmed (eds.), Technologies de l'information et développement économique local (Information Technology and Local Development), Paris, Publisud, 2004, pp. 20-67.

44. A number of examples were presented during the conference on regional innovation systems in China and the world. Sun Yat-sen University, Guangzhou, April 19th-21st 2004.

45. Kathlyn Walsh, Foreign Hi-tech in China. Risks, rewards and implications for USChina relations. Washington, D.C., Stimson Center, 2003 (http://www.stimson.org/ techtransfer/pdf/FinalReport.pdf).

46. The Guangdong government has repeatedly asked for reports on local production systems in Italy and France. Provincial officials carried out missions to France, Italy and India in 2000-2004. The government has also commissioned much research from Sun Yat-sen University, among others, in order to help its thinking. The conference on regional innovation systems in China and the world at Sun Yat-sen University, Guangzhou, in April 2004 was organised for the same reasons. The Blue Report is also based on academic research and is not the result of administrative reports. This desire to learn from foreign experience is not new in Guangdong; Adam Segal reports that the experiences of Taiwan, Hong Kong and Singapore have been the subject of similar reports.

\section{RÉSUMÉS}

This article examines industrial and technological growth in the province of Guangdong and the Pearl River Delta. It is based on a report drawn up by a team of researchers and professors under the authority of the Department of Science and Technology of Guangdong province, and on interviews with local authorities and enterprises. It examines the growth in Guangdong's research and technology system, enterprise investment in Research and Development (R\&D), the particular role of collective enterprises, the technological development zones, and the policy of industrial "clusters". Since 1999, the provincial authorities have sought to respond to the transformation of industrial space, by offering to set up a series of innovation centres located in specialised production areas. This article offers an initial assessment of this strategy of transforming industrial space into regional innovation space. 